\title{
FITOTECNIA
}

\section{PRODUTIVIDADE E QUALIDADE DA SILAGEM DE MILHO E SORGO EM FUNÇÃO DA ÉPOCA DE SEMEADURA $\left(^{1}\right.$ )}

\author{
RENZO GARCIA VON PINHO $\left({ }^{2 *}\right)$; RAMON CORREIA DE VASCONCELOS $\left({ }^{3}\right)$; IRAN DIAS BORGES $\left({ }^{4}\right)$; \\ ADAUTON VILELA DE RESENDE $\left({ }^{5}\right)$
}

\begin{abstract}
RESUMO
Com o objetivo de avaliar a influência de diferentes épocas de semeadura na produtividade e qualidade de cultivares de milho e sorgo para silagem e também verificar a possibilidade de substituição do milho pelo sorgo para produção de silagem, foram instalados experimentos em três épocas de semeadura, em área do Departamento de Agricultura da Universidade Federal de Lavras, no ano agrícola 2002/2003. Foram avaliados três grupos de cultivares - três cultivares de sorgo duplo propósito, três de sorgo forrageiro e três de milho, em três épocas de semeadura - 19/11/2002, 19/12/2002 e 18/1/2003). O delineamento utilizado foi o de blocos casualizados, em esquema fatorial 3 (grupos de cultivares) $\times 3$ (épocas de semeadura), com quatro repetições. Avaliaram-se produtividade de matéria seca (MS), participação de panícula ou espiga na MS, e as porcentagens de proteína bruta, fibra em detergente neutro (FDN), fibra em detergente ácido (FDA) e lignina. Observou-se efeito significativo para cultivares e épocas de semeadura para todas as características avaliadas. Constatou-se a presença de interação cultivares*épocas para a produtividade de matéria seca (MS), participação de panícula ou espiga na MS e porcentagem de proteína bruta. Independentemente de época semeadura, com o milho se tem silagem com menor teor de fibra do que com qualquer tipo de sorgo e produtividade de matéria seca semelhante à do sorgo forrageiro e maior do que o sorgo duplo propósito. A maior produção de matéria seca de milho e sorgo, para forragem, é obtida na semeadura em novembro. Silagem de milho e sorgo de maior valor nutritivo é obtida na semeadura de janeiro. Do ponto de vista de produção e de qualidade nutricional da forragem, não é viável a substituição da silagem de milho pela de sorgo.
\end{abstract}

Palavras-chave: Zea mays, Sorghum bicolor, Proteína bruta, FDN, FDA.

\section{ABSTRACT \\ PRODUCTIVITY AND QUALITY OF THE SILAGE OF CORN AND SORGHUM INFLUENCED BY THE TIME OF SOWING}

With the objective to evaluate the influence of different times of sowing in the productivity and silage quality of corn and sorghum cultivars and also of verifying the possibility of substitution of corn to sorghum to silage production, experiments were installed considering three times of sowing in area of the Department of Agriculture of the Federal University, during the agricultural year of 2002/2003.

$\left({ }^{1}\right)$ Recebido em 22 de novembro de 2005 e aceito para publicação em 11 de dezembro de 2006.

$\left({ }^{2}\right)$ Departamento de Agricultura da Universidade Federal de Lavras/UFLA. Campus Universitário - DAG/UFLA, Caixa postal 3037, 37200-000 Lavras (MG), E-mail: renzo@ufla.br. (*) Autor correspondente.

$\left({ }^{3}\right)$ Departamento de Fitotecnia e Zootecnia, UESB, 45000-000 Vitória da Conquista (BA), E-mail: ramonagm@uesb.br

$\left({ }^{4}\right)$ Departamento de Ciências Agrárias, Universidade Estadual de Montes Claros, UNIMONTES, (MG). E-mail: iran.borges@unimontes.br

$\left({ }^{5}\right)$ Departamento de Zootecnia, UNIFENAS, 37300-000 Alfenas (MG). E-mail: adauton.rezende@unifenas.br 
Three groups had been evaluated to cultivars (three of double purpose sorghum, three of forage sorghum and three of corn) at three times of sowing (19/11/2002, 19/12/2002, and 18/1/2003). The experimental design was of blocks randomized in factorial scheme 3 groups to cultivars (to cultivars) $\times 3$ times of sowing (times), with four repetitions. Productivity of dry matter was evaluated (MS), participation of panicle or spike in the MS, and the rude protein percentages, fiber in neutral detergent, fiber in acid detergent and lignin. Significant effect was observed to cultivars, times of sowing to all characteristics evaluated. The presence of interaction cultivars*times was verified for the productivity of dry matter, participation of panicle or spike in the MS and the rude protein percentages. Independently of times of sowing, with the corn present silage with smaller fiber tenor than with any sorghum types, and productivity of dry matter similar to the one of forage sorghum and superior to the one of sorghum of double intention. The largest production of dry matter of corn and sorghum was obtained when the sowing is made in November. Corn and sorghum silage of larger nutritional value was obtained when the sowing was made in January. Under the production point of view and of quality nutritional of the forage, it is not viable the substitution of the corn for sorghum.

Keys words: Zea mays, Sorghum bicolor, Crude protein, NDF, ADF.

\section{INTRODUÇÃO}

O milho e o sorgo são plantas forrageiras destacadamente utilizadas em silagem, devido à grande produção de forragem e composição da planta, resultando em fermentação adequada no silo e silagem de grande valor nutritivo.

A silagem de milho é tida como padrão e, geralmente, considerada referência para comparação de valor com outras silagens (Henrique et al., 1998). Contudo, sua produtividade e qualidade são incertas de ano para ano por serem influenciadas, dentre outros fatores, pela disponibilidade de água no solo (Nussio, 1991). Nesse contexto, o sorgo é uma cultura promissora, devido ao sistema radicular desenvolvido e outras características relacionadas à resistência à seca (Alvarenga, 1994), sendo favorecido seu cultivo na safrinha, com menores riscos do que na cultura do milho. Segundo Zago (1991), a tolerância à seca faz do sorgo uma das espécies preferidas para o cultivo na safrinha. Além disso, possui capacidade produtiva e valor nutritivo elevados e possibilidade de aproveitamento da rebrota, com produção de até $60 \%$ do primeiro corte.

Além de produzir mais forragem do que com o milho, com o sorgo se tem menor custo de produção, tendo em vista o menor consumo e preço das sementes. Geralmente, o valor nutritivo da silagem de sorgo é equivalente de $85 \%$ a $90 \%$ da silagem de milho, havendo, no entanto, referências mais elásticas, variáveis de $72 \%$ a $92 \%$ (Valente, 1992).

No sul de Minas Gerais tem-se uma das maiores bacias de produção de leite do Brasil, com grande potencial para o desenvolvimento adequado das culturas de milho e sorgo para uso como silagem, devido ao clima e solo e proximidade de centros consumidores; entretanto, o aproveitamento do sorgo como silagem, ainda é incipiente.
Várias são as dúvidas dos produtores no processo de produção das silagens de milho e sorgo. Dentre elas, estão a escolha da cultivar a ser utilizada e a definição da época mais adequada para a semeadura. Os períodos de crescimento e de desenvolvimento das culturas de milho e sorgo são influenciados pelos fatores climáticos, limitando-se à época de semeadura. Embora a época de semeadura recomendada no sul de Minas Gerais seja de 15 de outubro a 15 de novembro (Villela, 2001), os produtores a postergam até o fim de janeiro, principalmente para a produção de silagem. Em vista dessa variação, é esperado efeito negativo no crescimento e desenvolvimento da planta, podendo haver reflexos na produtividade e qualidade da forragem.

O objetivo desse trabalho foi avaliar a influência de diferentes épocas de semeadura na produtividade e qualidade de cultivares de milho e sorgo para silagem, visando à possibilidade de substituição do milho pelo sorgo.

\section{MATERIAL E MÉTODOS}

Foram desenvolvidos três experimentos em áreas contíguas do Departamento de Agricultura da Universidade Federal de Lavras, no município de Lavras (MG), situado na Região Sul do Estado de Minas Gerais, a $21^{\circ} 14^{\prime}$ de latitude Sul e $45^{\circ} 00^{\prime}$ de longitude Oeste, e na altitude de $920 \mathrm{~m}$ (Brasil, 1992). O clima da região é do tipo mesotérmico de inverno seco $(\mathrm{Cwb})$. As variações na temperatura e na precipitação pluvial, por decêndio, constatadas durante o desenvolvimento dos experimentos, estão apresentadas na figura 1 . O solo na área experimental foi classificado como Latossolo Vermelho- Escuro (LE), textura argilosa e declividade de $9 \%$, cujos resultados da análise química estão apresentados na tabela 1. 
Tabela 1. Análise química do solo $(0-20 \mathrm{~cm}$ de profundidade) em área onde foram instalados os experimentos. UFLA, Lavras (MG), 2004

\begin{tabular}{|c|c|c|c|c|c|c|c|c|c|}
\hline$\overline{\mathrm{pH} \text { em } \mathrm{H}_{2} \mathrm{O}}$ & M. O & $\mathrm{P}$ & K & $\mathrm{Ca}$ & $\mathrm{Mg}$ & $\mathrm{Al}+\mathrm{H}$ & $S$ & $\mathrm{~T}$ & $\mathrm{~V}$ \\
\hline & $\mathrm{g} \mathrm{dm}^{-3}$ & $\mathrm{mg} \mathrm{dm} \mathrm{m}^{-3}$ & $\mathrm{mg} \mathrm{dm}^{-3}$ & 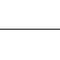 & 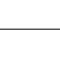 & $\mathrm{mol}_{\mathrm{c}} \mathrm{dm}$ & & & $\%$ \\
\hline 6,1 & - & 15,9 & 83 & 4,4 & 0,5 & $0,1+3,1$ & 5,1 & 8,3 & 61,5 \\
\hline
\end{tabular}

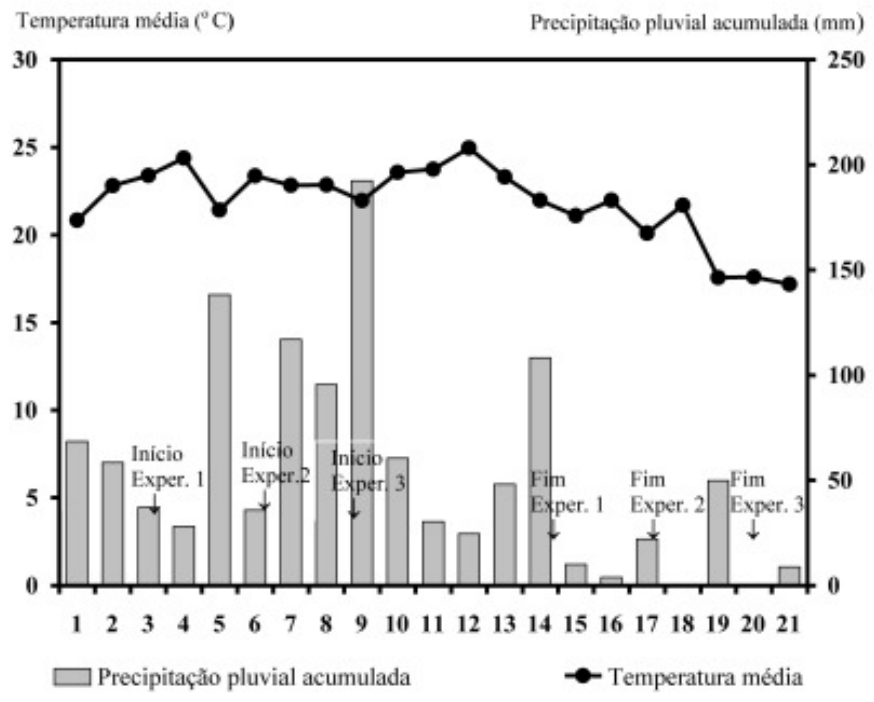

Figura 1. Dados de temperatura média e precipitação pluvial, por decêndio, em Lavras $M G$, no período de 1. $\% 11 / 2002$ a 30/05/03. Lavras (MG).

Os experimentos foram instalados em 19/11/ 2002, 19/12/2002, e 18/1/2003, utilizando-se nas adubações de semeadura $400 \mathrm{~kg} \mathrm{ha}^{-1}$ da formulação 08-28-16 + 0,5\% Zn. Foram realizadas duas adubações de cobertura, nos estádios de quatro a seis folhas definitivas e de sete a nove folhas definitivas, usandose, respectivamente, $300 \mathrm{~kg} \cdot \mathrm{ha}^{-1}$ de 20-00-20 e $150 \mathrm{~kg}$ .ha ${ }^{-1}$ de uréia. No preparo do solo, realizou-se uma aração e duas gradagens.
Foram avaliados três grupos de cultivares, constituídos de três cultivares de sorgo duplo propósito, três de sorgo forrageiro e três de milho (Tabela 2), nas três épocas de semeadura. Nas semeaduras utilizou-se o dobro de sementes necessárias à obtenção do estande desejado, realizando-se posterior desbaste quando as plantas atingiram $20 \mathrm{~cm}$ de altura, considerando-se os estandes de 60.000 plantas ha ${ }^{-1}$ para o milho, 150.000 plantas ha ${ }^{-1}$ para o sorgo duplo propósito e 130.000 plantas ha ${ }^{-1}$ para o sorgo forrageiro. As plantas de milho foram colhidas quando a "linha de leite" estava na posição de 2/3 do grão (Fancelli e Dourado Neto, 2000) e, as plantas de sorgo, quando os grãos estavam no estádio farináceo (Evangelista e Lima, 2000). No controle de plantas infestantes, realizou-se capina manual aos 25 dias após a semeadura.

Os experimentos foram instalados, adotandose o delineamento de blocos casualizados, em esquema fatorial 3 (grupos de cultivares) x 3 (épocas de semeadura), com quatro repetições. A parcela experimental foi constituída por quatro fileiras de cinco metros de comprimento, espaçadas de $0,7 \mathrm{~m}$, sendo consideradas úteis as duas centrais.

As características agronômicas avaliadas foram dias para a colheita, altura e estande final de plantas, porcentagem de plantas acamadas e quebradas, proporção de espigas ou panículas na matéria seca - MS e produtividade de MS.

Tabela 2. Características das cultivares de sorgo e milho, avaliadas nos experimentos. UFLA, Lavras (MG), 2004

\begin{tabular}{lcccc}
\hline Cultivar & Tipo de cultivar & Ciclo fenológico & Empresa & Tipo de grão \\
\hline Sorgo: & & & Dow & Sem tanino \\
Massa 3 & Híbrido D. propósito & Normal & Agroceres & Sem tanino \\
AG 2005 E & Híbrido D. propósito & Normal & Com tanino \\
BRS 701 & Híbrido D. propósito & Normal & Agroceres & Sem tanino \\
Volumax & Híbrido forrageiro & Tardio & Bayer & Sem tanino \\
BRS 601 & Híbrido forrageiro & Tardio & Agroceres & Sem tanino \\
AG 2002 & Híbrido forrageiro & Tardio & & Agroceres \\
Milho: & & & Agroceres & Dentado \\
AG 4051 & Híbrido triplo & Normal & Syngenta & Duro \\
AG 1051 & Híbrido duplo & Normal & Precoce & \\
TORK & Híbrido simples & &
\end{tabular}


A altura de plantas foi determinada na ocasião da colheita, medindo-se do nível do solo até a inserção da última folha, em cinco plantas competitivas na parcela. O estande final de plantas foi obtido contandose o número de plantas na área útil da parcela, por ocasião da colheita, valor transformado em plantas ha' ${ }^{1}$. Para plantas acamadas e quebradas contou-se, antes da colheita, as plantas acamadas, com ângulo superior a $20^{\circ} \mathrm{com}$ a vertical ou quebradas abaixo da espiga ou panícula, cujos valores foram transformados em porcentagem. O número de dias para a colheita correspondeu aos dias entre a emergência das plantas e o corte para a ensilagem.

A produtividade de matéria seca foi correspondente ao valor obtido após a correção da produção de matéria verde pela porcentagem de matéria seca obtida a $105^{\circ} \mathrm{C}$. A massa média obtida na área útil da parcela foi transformada em $\mathrm{kg} \mathrm{ha}^{-1}$. A proporção de panículas ou espigas na MS foi obtida pela relação entre a massa de MS das panículas e/ ou espigas e a massa total de MS das plantas.

Para a ensilagem foram retiradas duas amostras de plantas na área útil de cada parcela. A primeira amostra de dez plantas foi agrupada, identificada e triturada (partículas de $2,5 \mathrm{~cm}$ ) em picadora de forragem e homogeneizada. Em seguida foi retirada uma amostra de $300 \mathrm{~g}$, e seca em estufa de aeração forçada a uma temperatura de $55{ }^{\circ} \mathrm{C}$ por 72 horas, para determinação da MS da forragem. O restante do material triturado foi ensilado por 35 dias, em minissilos confeccionados a partir de tubos de PVC com $10 \mathrm{~cm}$ de diâmetro e $50 \mathrm{~cm}$ de altura. Após a abertura dos silos, determinou-se a MS da silagem, retirando-se uma amostra de $300 \mathrm{~g}$, que foi seca em estufa de ventilação forçada, a uma temperatura de $55{ }^{\circ} \mathrm{C}$ por 72 horas. Posteriormente, essa amostra foi moída em moinho tipo Willey, com peneira de $1 \mathrm{~mm}$ de crivo para a determinação da MS a $105{ }^{\circ} \mathrm{C}$ (AACC, 1976) e realização das análises bromatológicas.

A segunda amostra, composta de três plantas, também foi agrupada, identificada e levada até o laboratório, onde foi fracionada em colmo + folhas e espigas ou panículas. As duas frações foram pesadas separadamente e secas em estufa de aeração forçada a $55^{\circ} \mathrm{C}$ por 72 horas. Foi então determinada a MS das frações da planta (AACC, 1976) e, posteriormente, a proporção de cada fração na MS total da planta.

Para porcentagem de proteína bruta (PB) avaliou-se o teor de nitrogênio, utilizando-se o aparelho de destilação a vapor micro-Kjedahl, conforme AOAC (1970); o teor de proteína bruta foi calculado utilizando-se o fator de conversão 6,25. As porcentagens de fibra em detergente neutro (FDN) e de fibra em detergente ácido (FDA) foram determinadas por análise não seqüencial, segundo método descrito por VAN SOEST et al. (1991). Na técnica de FDN utilizaram-se 0,5 g de sulfito de sódio e 200 $\mu \mathrm{L}$ de alfa amilase. A porcentagem de lignina (LIG) foi determinada por meio de hidrólise ácida, de acordo com VAN Soest et al. (1991).

As determinações bromatológicas das silagens foram realizadas no laboratório de nutrição animal da Universidade Federal de Lavras. Para todas as análises foram realizadas duplicatas das amostras obtidas em cada parcela.

Os valores obtidos para as características agronômicas e bromatológicas em cada experimento foram submetidos à análise de variância. Posteriormente, foi realizada uma análise de variância conjunta, considerando-se os três experimentos. Todas as análises, incluindo-se o estudo de regressão, foram feitas, utilizando-se o programa estatístico SISVAR (FerReira, 1999). As médias foram agrupadas por contrastes ortogonais, considerando-se os diferentes tipos de sorgo e as cultivares de milho, a $5 \%$ de probabilidade.

\section{RESULTADOS E DISCUSSÃO}

Os valores médios obtidos para o número de dias para o corte das plantas das cultivares, estande final e altura de plantas e plantas acamadas e quebradas nos grupos de cultivares de milho e sorgo, nas três épocas de semeadura, estão apresentados na tabela 3. Não foram realizadas análises estatísticas para essas características.

Foi verificada redução na altura das plantas de todas as cultivares de sorgo e de milho com o atraso na semeadura (Tabela 3). Resultados semelhantes foram obtidos por RAMALHO (1999), que constatou decréscimo médio diário de $1,0 \mathrm{~cm}$ na altura da planta de milho, por dia de atraso na semeadura a partir de 15 de outubro.

As médias de produtividade de MS de forragem (MS) e porcentagem de espiga ou panícula na MS (PEMS) nos grupos de cultivares de milho e de sorgo, incluindo-se as três épocas de semeadura, o erropadrão da média (EPM) e os valores dos níveis descritivos $(\operatorname{Pr}>\mathrm{F})$ das respectivas análises de variância estão apresentados na tabela 4.

Para as características MS e PEMS, verificouse efeito significativo para grupos de cultivares, épocas de semeadura e para a interação cultivares*épocas (Tabela 4.). A constatação da interação grupo*época, é indicativa do comportamento diferenciado dos grupos de cultivares nas três épocas de semeadura, para essas duas características. 
Na semeadura de novembro de 2002, a produtividade de MS das cultivares de milho e sorgo forrageiro foi maior do que a das cultivares de sorgo duplo propósito. Na semeadura de dezembro/2002 a produtividade de MS entre os grupos foi semelhante. $\mathrm{Na}$ semeadura de janeiro/2003, obteve-se maior produtividade de MS nas cultivares de milho, em relação aos sorgos duplo propósito.

Resultados semelhantes foram relatados por outros autores, segundo os quais têm sido constatados valores de produtividade de MS variáveis de 8,0 tha' 1 a 23,0 t ha ${ }^{-1}$ para a cultura do milho (MeLo et al., 1998; Fonseca, 2000; Villela, 2001) e de $8,8 \mathrm{t} \mathrm{ha}^{-1}$ a
16,6 t ha ${ }^{-1}$ para a cultura do sorgo (BRITO, 1995; REZENDE, 2001).

As diferenças de produtividade entre os grupos de cultivares podem estar relacionadas, principalmente, com o porte da planta, condicionando-se menor produtividade de matéria seca nos materiais mais baixos. RibEIRO (1998) verificou que, nas semeaduras tardias, tem-se redução na altura de plantas de milho e no número de espigas despalhadas. Quinby (1974), trabalhando com sorgo de porte alto, e Assis et al. (1984), avaliando cultivares de sorgo granífero, verificaram diminuição na altura das plantas com o atraso na semeadura e conseqüente diminuição na MS.

Tabela 3. Dias para a colheita, estande final, altura de plantas (AP) e plantas acamadas e quebradas (PAQ) em grupos de cultivares de milho e sorgo avaliados em três épocas de semeadura. UFLA, Lavras (MG), 2004

\begin{tabular}{|c|c|c|c|c|}
\hline \multirow[b]{2}{*}{ Cultivares } & \multicolumn{3}{|c|}{ Época I (Novembro de 2002) } & \multirow[b]{2}{*}{ PAQ } \\
\hline & Dias para colheita & Estande final & $\mathrm{AP}$ & \\
\hline & & plantas $\mathrm{ha}^{-1}$ & $-\mathrm{m}-$ & $-\%-$ \\
\hline Sorgo duplo propósito & 113 & 134.134 & 1,7 & 0,0 \\
\hline Sorgo forrageiro & 126 & 127.351 & 3,0 & 3,4 \\
\hline Milho & 123 & 59.047 & 2,7 & 1,8 \\
\hline \multicolumn{5}{|c|}{ Época II (Dezembro de 2002) } \\
\hline Sorgo duplo propósito & 106 & 139.663 & 1,6 & 0,0 \\
\hline Sorgo forrageiro & 118 & 123.740 & 2,6 & 6,2 \\
\hline Milho & 118 & 55.238 & 2,3 & 1,0 \\
\hline \multicolumn{5}{|c|}{ Época III (Janeiro de 2003) } \\
\hline Sorgo duplo propósito & 121 & 133.235 & 1,45 & 0,42 \\
\hline Sorgo forrageiro & 121 & 111.944 & 2,17 & 34,17 \\
\hline Milho & 121 & 56.071 & 2,10 & 4,00 \\
\hline
\end{tabular}

Tabela 4. Produtividade de matéria seca (MS) e proporção de espigas ou panículas na MS (PEMS) em grupos de cultivares de milho e sorgo avaliados, em três épocas de semeadura. UFLA, Lavras (MG), 2004

\begin{tabular}{|c|c|c|c|c|c|c|c|}
\hline \multirow{2}{*}{ Variáveis } & \multirow{2}{*}{$\operatorname{SDP}\left({ }^{1}\right)$} & \multirow{2}{*}{ SF } & \multirow{2}{*}{ M } & \multirow{2}{*}{ EPM } & \multirow{2}{*}{$\begin{array}{c}\mathrm{P}\left({ }^{2}\right) \\
\text { Grupos dentro de épocas }\end{array}$} & \multicolumn{2}{|c|}{$P$ contrastes $\left({ }^{2}\right)$} \\
\hline & & & & & & SDP vs M & SF vs $M$ \\
\hline \multicolumn{8}{|c|}{ Época I (Novembro de 2002) } \\
\hline MS $\left(\mathrm{tha}^{-1}\right)$ & 14,4 & 21,0 & 20,0 & 0,77 & 0,0000 & 0,000 & 0,391 \\
\hline PEMS (\%) & 29,8 & 17,7 & 41,3 & 1,40 & 0,0000 & 0,000 & 0,000 \\
\hline \multicolumn{8}{|c|}{ Época II (Dezembro de 2002) } \\
\hline MS $\left(\mathrm{t} \mathrm{ha}^{-1}\right)$ & 15,9 & 17,6 & 15,7 & 0,77 & 0,1576 & 0,896 & 0,086 \\
\hline PEMS (\%) & 28,9 & 18,5 & 46,9 & 1,40 & 0,0000 & 0,000 & 0,000 \\
\hline \multicolumn{8}{|c|}{ Época III (Janeiro de 2003) } \\
\hline $\operatorname{MS}\left(\mathrm{t} \mathrm{ha}^{-1}\right)$ & 9,5 & 10,4 & 12,4 & 0,77 & 0,0264 & 0,008 & 0,077 \\
\hline PEMS (\%) & 30,1 & 25,3 & 42,0 & 1,40 & 0,0000 & 0,000 & 0,000 \\
\hline
\end{tabular}

(1) SDP: sorgo duplo propósito; SF: sorgo forrageiro; M: milho; EPM: erro-padrão da média.

$\left({ }^{2}\right)$ Níveis de significância - probabilidade dos efeitos de grupos de cultivares dentro de épocas e dos contrastes, sorgo duplo propósito versus milho e sorgo forrageiro versus milho. 
A produtividade de MS pode ainda estar direta e positivamente relacionada ao ciclo da cultivar, conforme dados na tabela 4 .

Foi obtida relação linear significativa para produtividade de MS das cultivares de sorgo forrageiro e de milho, nas diferentes épocas de semeadura, e regressão quadrática significativa para as cultivares de sorgos duplo propósito, sendo os coeficientes de determinação superiores a 95\% (Figura 2). Constatou-se decréscimo de $176 \mathrm{~kg} \mathrm{ha}^{-1}$ na produtividade de MS para cada dia de atraso na semeadura a partir de 19/11/2002 para o sorgo forrageiro, e de $128 \mathrm{~kg} \mathrm{ha}^{-1}$ para o milho; já para o sorgo duplo propósito foi verificado acréscimo na produtividade de MS até o $21 .^{\circ}$ dia de atraso na semeadura, com valor de $16,22 \mathrm{t} \mathrm{ha}^{-1}$; a partir de então, com os atrasos na semeadura houve redução na produtividade. Devido à escassez de chuvas, registrada no terço final do período experimental (Figura 1), provavelmente foi prejudicada a produtividade de MS das cultivares de milho e sorgo na semeadura de janeiro/2003.

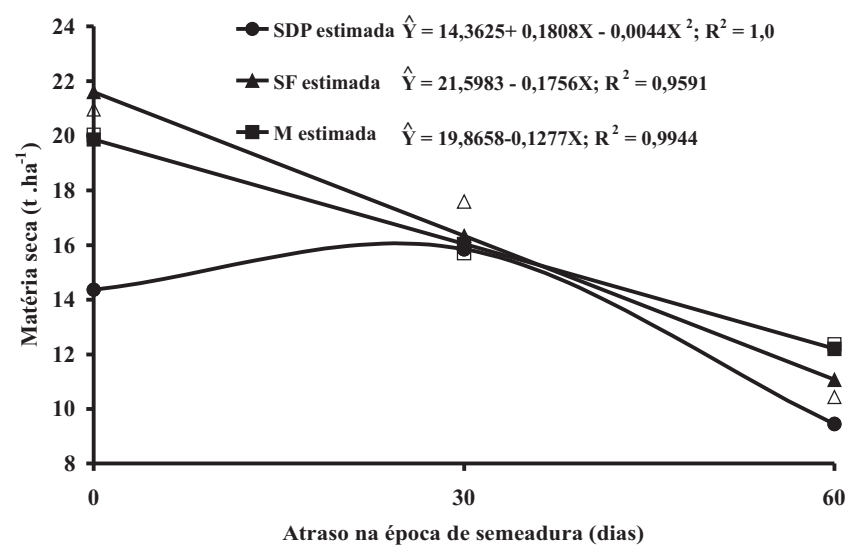

Figura 2. Representação gráfica das equações de regressão para os resultados de produtividade de $\mathrm{MS}\left(\mathrm{t} \mathrm{ha}^{-1}\right)$, sendo expresso o efeito médio das épocas de semeadura - dias de atraso em relação a 19/11/2002 (SDP - sorgo duplo propósito; SF - sorgo forrageiro e M - milho) UFLA, Lavras (MG), 2004.

Esses resultados são corroborados com os obtidos por Ramalho (1999) que, avaliando o comportamento de famílias de meio-irmãos em diferentes épocas de semeadura, visando à produção de milho para forragem, obteve decréscimo de $114 \mathrm{~kg}$ $\mathrm{ha}^{-1}$ na produtividade de MS, por dia de atraso na semeadura, a partir de 15 de outubro. Villela (2001) também verificou redução na produção de MS com o atraso na semeadura, evidenciando-se a importância da escolha de cultivares em função da época de semeadura.
Para o percentual de espigas ou de panículas na MS (PEMS), constatou-se comportamento diferenciado entre os grupos de cultivares, em cada época de semeadura. De maneira geral, independentemente da época de semeadura, o percentual de espigas de milho foi sempre superior ao de panículas do sorgo forrageiro que, por sua vez, foi sempre inferior ao de panículas do sorgo duplo propósito. Devido aos menores percentuais de panículas nas cultivares de sorgo forrageiro, verificaram-se os menores percentuais de grãos na MS nessas cultivares, o que pode ser explicado pelas suas características forrageiras (Tabela 4).

Foi obtida relação linear significativa para porcentagem de panículas ou de espigas na MS das cultivares de sorgo forrageiro e relação quadrática significativa para as cultivares de milho e as diferentes épocas de semeadura, sendo os coeficientes de determinação $82,9 \%$ e $100 \%$ respectivamente (Figura 3). Constatou-se acréscimo de 0,13\% na proporção de panícula na MS, para cada dia de atraso na semeadura do sorgo forrageiro, a partir de 19/11/ 2002. Para o milho, houve acréscimo na porcentagem de espigas na MS com até 31 dias de atraso na semeadura, atingindo-se $52 \%$; a partir daí, com os atrasos na semeadura foi proporcionada redução na porcentagem de espiga na MS.

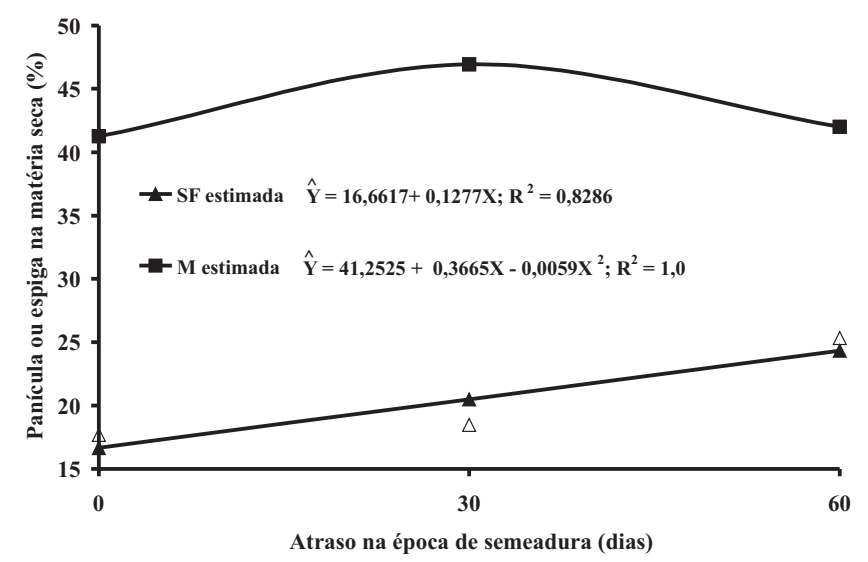

Figura 3. Representação gráfica das equações de regressão para os resultados de porcentagem de espiga ou panícula na MS (\%), sendo expresso o efeito médio das épocas de semeadura - dias de atraso em relação a 19/ 11/2002 (SF - sorgo forrageiro e M - milho), UFLA, Lavras (MG), 2004.

Souza (1989), comparando 17 cultivares de milho nos municípios mineiros de Lavras e Sete Lagoas, verificou que, com o atraso na semeadura foram acarretadas reduções expressivas na produção de grãos. A porcentagem de panícula ou de espigas na MS está muito relacionada com a produção de grãos. A escolha de cultivares de maior produção de 
grãos tem sido critério amplamente utilizado na escolha de cultivares de milho ou de sorgo para produção de silagem (Hunter, 1978; Penati, 1995).

As médias de porcentagem de proteína bruta na MS (PB), FDN, FDA e lignina nos grupos de cultivares de milho e sorgo, nas três épocas de semeadura, o erro-padrão da média (EPM), os valores dos níveis descritivos $(\mathrm{P})$ e as respectivas análises de variância, estão apresentados nas tabelas 5 e 6 . Para PB foi constatado efeito significativo para cultivares, épocas e para a interação cultivares*épocas, sendo esse último indicativo do comportamento diferenciado nos grupos de cultivares, nas três épocas de semeadura, para essa característica.

Nas semeaduras de 19/11/2002 e 19/12/ 2002 , foram verificados menores teores de proteínas nas cultivares de milho em relação aos de sorgos de duplo propósito. Em dezembro/2002, o comportamento foi semelhante para essa característica nas cultivares de milho e de sorgo forrageiro (Tabela 5). Na semeadura de janeiro/ 2003, nas cultivares de milho foram obtidos menores teores de proteína bruta do que nos dois grupos de cultivares de sorgo (Tabela 5).

Os valores de PB obtidos neste trabalho (Tabela 5), variáveis, em média, de $7,1 \%$ a $9,5 \%$ para o sorgo e de $7,5 \%$ a $8,6 \%$ para o milho, podem ser considerados muito adequados. Keplin e Santos (1996) afirmam que, uma silagem, para ser considerada de boa qualidade, deve ter de $7,1 \%$ a $8,0 \%$ de PB. Flaresso et al. (2000) constataram teores de $\mathrm{PB}$ para milho variáveis de $7,7 \%$ a $8,9 \%$ e, para sorgo, entre $6,3 \%$ a $7,7 \%$, valores próximos aos verificados neste trabalho.

Tabela 5. Porcentagem de proteína bruta $(\mathrm{PB})$ em grupos de cultivares de milho e sorgo, em três épocas de semeadura. UFLA, Lavras (MG), 2004.

\begin{tabular}{lcccccc}
\hline Variáveis & SDP $\left({ }^{1}\right)$ & SF & M & EPM & P $\left(^{2}\right)$ & \multicolumn{2}{c}{ P contrastes $\left(^{2}\right)$} \\
\cline { 4 - 7 } & & & & Época I (Novembro de 2002) & SDP vs M vs M \\
\hline PB (\%) & 8,2 & 7,1 & 7,5 & 0,13 & 0,0000 & 0,000 \\
\hline PB (\%) & 9,2 & 8,1 & 8,3 & 0,13 & 0,0000 & 0,000 \\
\hline PB (\%) & 9,5 & 9,0 & 8,6 & 0,13 & Época III (Janeiro de 2003) & 0,215 \\
\hline
\end{tabular}

$\left({ }^{1}\right)$ SDP: sorgo duplo propósito; SF: sorgo forrageiro; M: milho; EPM: erro-padrão da média.

$\left({ }^{2}\right)$ Níveis de significância - probabilidade dos efeitos de grupos de cultivares dentro de épocas e dos contrastes, sorgo duplo propósito versus milho e sorgo forrageiro versus milho.

Tabela 6. Porcentagens de fibra em detergente neutro (FDN), fibra em detergente ácido (FDA) e lignina em grupos de cultivares de milho e sorgo, em três épocas de semeadura. UFLA, Lavras (MG), 2004

\begin{tabular}{|c|c|c|c|c|c|c|c|c|c|}
\hline \multirow{2}{*}{ Variáveis } & \multirow{2}{*}{$\mathrm{SDP}^{(1)}$} & \multirow{2}{*}{ SF } & \multirow{2}{*}{$\mathrm{M}$} & \multirow{2}{*}{ EPM } & \multicolumn{3}{|c|}{$\mathrm{P}\left({ }^{2}\right)$} & \multicolumn{2}{|c|}{$P$ contrastes $\left({ }^{2}\right)$} \\
\hline & & & & & Grupos & Épocas & $G^{*} E$ & SDP vs M & SF vs M \\
\hline FDN & 42,9 & 45,8 & 38,8 & 0,67 & 0,0000 & 0,0000 & 0,0858 & 0,000 & 0,000 \\
\hline FDA & 26,2 & 28,6 & 22,1 & 0,50 & 0,0000 & 0,0104 & 0,1126 & 0,000 & 0,000 \\
\hline Lignina & 6,3 & 6,4 & 6,5 & 0,13 & 0,5324 & 0,0018 & 0,3815 & 0,263 & 0,593 \\
\hline
\end{tabular}

(1) SDP: sorgo duplo propósito; SF: sorgo forrageiro; M: milho; EPM: erro-padrão da média.

$\left(^{2}\right)$ Níveis de significância - probabilidade dos efeitos de grupos de cultivares dentro de épocas e dos contrastes, sorgo duplo propósito versus milho e sorgo forrageiro versus milho. 
Os maiores teores de PB obtidos nas cultivares de sorgo duplo propósito, em relação ao sorgo forrageiro, deve-se à maior proporção de panículas na MS obtida nesse grupo de cultivares. Segundo RESENDE (2001), com maior proporção tanto de panículas quanto de espigas na MS obtém-se maior porcentagem de PB. Foram estabelecidas relações lineares significativas entre a porcentagem de proteína bruta na MS nos grupos de cultivares de sorgo duplo propósito, sorgos forrageiros e milho, e as diferentes épocas de semeadura, com as equações de regressão $Y=8,2950+0,230 X\left(R^{2}=0,91\right), Y=7,1417+0,0309 X$ $\left(\mathrm{R}^{2}=0,99\right)$ e $\mathrm{Y}=7,5713+0,0186 \mathrm{X} \quad\left(\mathrm{R}^{2}=0,93\right)$ respectivamente. Na semeadura de 18/1/2003, foram obtidos os maiores valores de $\mathrm{PB}$, independentemente do grupo de cultivares (Tabela 5), o que está relacionado com a maior proporção de panículas ou de espigas na MS constatada nessa época de semeadura. Foram verificados acréscimos de $0,023 \%$, 0,031\%, e 0,019\% nas porcentagens de proteína bruta na MS nas cultivares de sorgo duplo propósito, sorgo forrageiro e milho, respectivamente, para cada dia de atraso na semeadura, a partir de 19/11/2002, indicativo de que a PB está presente em maior quantidade nos grãos, pois a proporção de panículas ou espigas também foi aumentada com o atraso na semeadura.

As médias das porcentagens de fibra em detergente neutro (FDN), de fibra em detergente ácido (FDA) e de lignina (LIG) nos grupos de cultivares de milho e sorgo, avaliados nas três épocas de semeadura, assim como o erro-padrão da média (EPM), os valores dos níveis descritivos $(\mathrm{Pr}>\mathrm{F})$ e as respectivas análises de variância, estão apresentados na tabela 6.

Entre os grupos de cultivares, foi constatado efeito significativo para as porcentagens de FDN e de FDA. Para a porcentagem de lignina o comportamento foi semelhante nos diferentes grupos de cultivares. Para a época de semeadura, foi verificada diferença significativa para as porcentagens de FDN, de FDA e lignina, indicativo de comportamento diferencial dessas características nas três épocas de semeadura. Entretanto, não se observou diferença significativa na interação cultivares*épocas, para essas três variáveis, comportamento coincidente ao dos grupos de cultivares nas três épocas de semeadura. Foram verificados percentuais de FDN inferiores nos cultivares de milho em relação aos dos dois tipos de sorgo (Tabela 5).

Avaliou-se a relação quadrática significativa entre porcentagem de FDN na MS e as diferentes épocas de semeadura (Figura 4). Até o $20 .^{\circ}$ dia de atraso na semeadura observou-se decréscimo na porcentagem de FDN, atingindo-se um mínimo de $39,4 \%$, a partir de quando, com os atrasos na semeadura, proporcionam-se aumentos na FDN. Melo et al. (1998) e REZENDE (2001) obtiveram valores de FDN entre $43,45 \%$ e $60,98 \%$ e entre $44,8 \%$ e $60,4 \%$ nas culturas do milho e do sorgo, respectivamente, valores superiores aos constatados neste trabalho, sobretudo em sorgo. Os pequenos valores de FDN determinados neste trabalho foram decorrentes, possivelmente, da maior proporção de panículas ou de espigas na MS com menores proporções de colmos e folhas na MS e, conseqüentemente, com redução na porcentagem de fibra na silagem. Níveis adequados de FDN para o milho quando são aqueles inferiores a 50\% (Fancelli e Dourado Neto, 2000; Cruz e Pereira Filho, 2001).

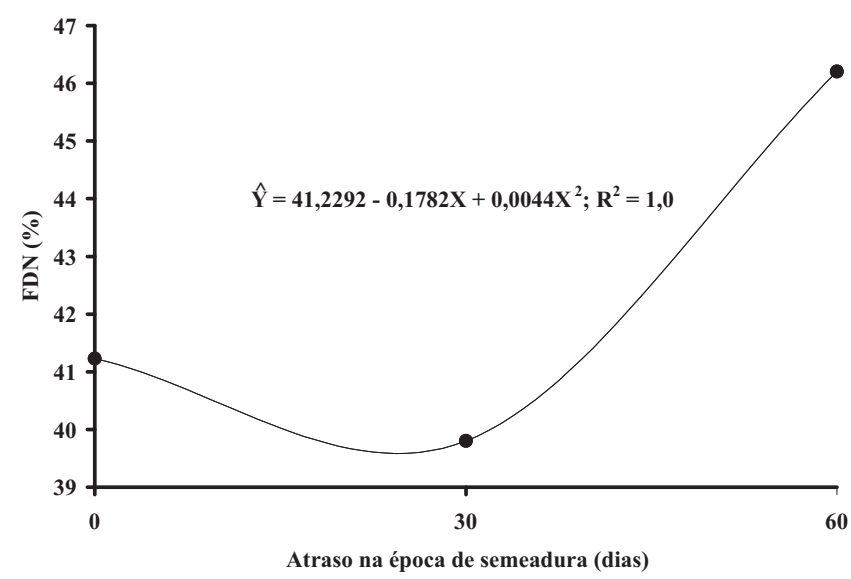

Figura 4. Representação gráfica da equação de regressão estimada para os resultados de porcentagem de fibra em detergente neutro na matéria seca, sendo expresso o efeito médio das épocas de semeadura - dias de atraso em relação à 19/11/2002, UFLA, Lavras (MG), 2004.

Existe uma tendência de associação da porcentagem FDN à proporção de panículas na massa ensilada, a qual está relacionada aos diferentes tipos de sorgo (duplo propósito e forrageiro). Menegaz (2002) constatou valores de FDN inferiores em sorgo duplo propósito quando comparado aos do sorgo forrageiro.

A redução no percentual de FDN, da primeira para a segunda época de semeadura pode, em parte, ser explicada, pelas temperaturas e precipitações pluviais elevadas no período (Figura 1); essas condições nas quais é acelerada a atividade metabólica das células, resultam em acréscimo do conjunto de metabólitos no conteúdo celular, e menor lignificação da parede celular. Por outro lado, o aumento nos percentuais de FDN na terceira época de semeadura pode ser explicado, em parte, pela redução drástica das precipitações pluviais verificadas durante o ciclo das cultivares (Figura 1). 
Nos três grupos de cultivares os comportamentos foram semelhantes para a porcentagem de FDA, nas três épocas de semeadura. Obteve-se relação quadrática significativa entre a porcentagem de FDA na MS e as diferentes épocas de semeadura (Figura 5). Entretanto, nas cultivares de milho foram obtidos percentuais de FDA inferiores aos das cultivares de sorgo. Verificou-se decréscimo na porcentagem de FDA até o $25 .^{\circ}$ dia de atraso na semeadura, a partir de $19 / 11 / 2002$, quando se atingiu um mínimo de $24,53 \%$; a partir daí, com os atrasos na semeadura foram proporcionados aumentos na FDA.

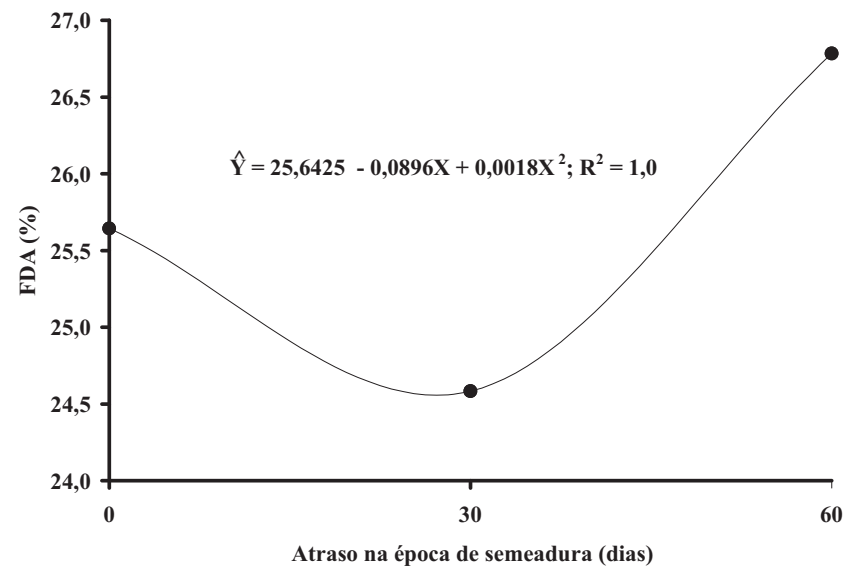

Figura 5. Representação gráfica da equação de regressão estimada para os resultados de porcentagem de fibra em detergente ácido na matéria seca, sendo expresso o efeito médio das épocas de semeadura - dias de atraso em relação a 19/11/2002, UFLA, Lavras (MG), 2004.

Melo et al. (1998) e Rezende (2001) determinaram valores de FDA variáveis de $22,66 \%$ a $31,06 \%$ e de $26,5 \%$ a $40,6 \%$ nas culturas do milho e do sorgo respectivamente. Esses valores são semelhantes aos obtidos neste trabalho. Já FONSECA (2000), avaliando 60 cultivares de sorgo semeadas na segunda semana de novembro, verificou valores percentuais de FDA na MS da silagem de $23,26 \%$ a $40,33 \%$. Os pequenos valores obtidos para a porcentagem de FDA, nas três épocas de semeadura, para a maioria das cultivares, provavelmente foram parcialmente devidos à grande proporção de panículas e/ou espigas na MS e aos pequenos valores percentuais de FDN na MS total da planta.

De modo geral, na terceira época de semeadura, nos grupos de cultivares foram constatados maiores percentuais de FDA, o que pode ser explicado pelos maiores percentuais de fibra na MS total. Foi verificado que, com os sorgos forrageiros, obteve-se maior percentual de FDA do que com os sorgos duplo propósito e com as cultivares de milho. Nas cultivares de milho de porte elevado e com menor produção de grãos, há grande concentração de componentes da parede celular - celulose, hemicelulose e lignina e, por esse motivo, a porção fibrosa é elevada. Na escolha de cultivares para produção de silagem, deve-se dar prioridade àqueles com menor porcentagem de FDA, com o que se proporciona maior digestibilidade.

Para o teor de lignina, o comportamento dos grupos de cultivares foi semelhante nas três épocas de semeadura (Tabela 6). Foi estabelecida relação quadrática significativa entre a porcentagem de FDA na MS e as diferentes épocas de semeadura, obtendose equação de regressão $Y=6,5631+0,0152 X$ $0,0004 X^{2}\left(R^{2}=100 \%\right)$. Verificou-se acréscimo na porcentagem de lignina até o $19 .^{\circ}$ dia de atraso na semeadura, atingindo-se o máximo de 6,7\%. A partir do $25 .^{\circ}$ dia, com os atrasos na semeadura, foram constatadas diminuições na porcentagem de lignina. FonseCa (2000) e AlFaya (2002) determinaram valores de lignina variáveis de $9,08 \%$ a $15,95 \%$ e de $4,4 \%$ a $4,7 \%$, respectivamente, para as culturas do milho e do sorgo. Entretanto, os valores obtidos por FONSECA (2000), no milho, foram muito diferentes daqueles avaliados neste trabalho. Esse autor atribui os elevados valores na lignina ao método de determinação utilizado.

A porcentagem de lignina é considerada um dos principais fatores limitantes da digestibilidade da parede celular em forrageiras (Wolf et al., 1993) e com sua determinação é possível a discriminação dos cultivares com relação à sua qualidade forrageira.

Independentemente da época de semeadura, obtém-se com o milho silagem com menor teor de fibra do que com qualquer tipo de sorgo e produtividade de matéria seca semelhante à do sorgo forrageiro e superior à do sorgo duplo propósito.

\section{CONCLUSÕES}

1. A maior produção de matéria seca de milho e sorgo, para forragem, é obtida na semeadura em novembro.

2. Silagem de milho e sorgo de maior valor nutritivo é obtida na semeadura de janeiro.

3. Sob o ponto de vista de produção e de qualidade nutricional da forragem não é viável a substituição da silagem de sorgo pela de milho. 


\section{REFERÊNCIAS}

ALFAYA, H. et al. Estudo comparativo de silagens de híbridos de sorgo (Sorghum bicolor L. MOENCH). II Valor nutritivo. In: REUNIÃO ANUAL DA SOCIEDADE BRASILEIRA DE ZOOTECNIA, 39., 2002, Recife. Anais... Recife: SBZ, 2002. 1 CD.

ALVARENGA, M. C. V. Consumo e digestibilidade aparente de silagens de sorgo (Sorghum vulgare Pers) em três momentos de corte e dois tamanhos de partículas, em carneiros. 1994. 82p. Dissertação (Mestrado em Zootecnia)Universidade Federal de Minas Gerais, Belo Horizonte, 1994.

AMERICAN ASSOCIATION OF CEREAL CHEMISTS (AACC). Approved methods of the American Association of Cereal Chemists. 7.ed. St. Paul, 1976. 256p.

ASSIS, F. N.; MENDEZ, M. E. G.; SCHUCH, L. O. B. Resposta de dois híbridos comerciais de sorgo granífero a diferentes épocas de semeaduras em Pelotas, RS, 1982/83. In: REUNIÃO TÉCNICA ANUAL DE SORGO, 12., Pelotas, 1983. Anais... Pelotas: EMBRAPA - UEPAE, 1984. p.81-84.

\section{ASSOCIATION OF OFFICIAL ANALYTICAL CHEMISTS}

(AOAC). Official Methods of Analyses of the Association of Official Analytical Chemists. 11.ed. Washington, 1970. v.1, 1015p.

BRASIL. Ministério da Agricultura e Reforma Agrária. Normais climatológicas 1961-1990. Brasília: MARA, 1992. 84p.

BRITO, G. Q. Características agronômicas, composição química, qualidade e consumo das silagens de duas variedades e três híbridos de sorgo forrageiro. 1995. 67p. Dissertação (Mestrado em Zootecnia)- Escola Superior de Agricultura Luiz de Queiroz, Piracicaba, 1995.

CRUZ, J. C., PEREIRA FILHO, I. A. Cultivares de milho para silagem. In: CRUZ, J. C. et al. (Ed.). Produção e utilização de silagem de milho e sorgo. Sete Lagoas: Embrapa Milho e Sorgo, 2001. p. 11-37.

EVANGELISTA, A. R.; LIMA, J. A. Silagens: do cultivo ao silo. Lavras: UFLA, 2000. 196p.

FANCELLI, A. L.; DOURADO NETO, D. Produção de milho. Guaíba: Agropecuária, 2000. 360 p.

FERREIRA, D. F. SISVAR: Sistema de análise de variância. Versão 3.04. Lavras: UFLA/DEX, 1999. 1 disquete.

FLARESSO, J. A. ; GROSS, C. D.; ALMEIDA, E. X. Cultivares de milho (Zea mays L.) e sorgo (Sorghum bicolor L. Moench) para ensilagem no Alto Vale do Itajaí, Santa Catarina. Revista da Sociedade Brasileira de Zootenia, Piracicaba, v.29, n.6, p.16081615, 2000.

FONSECA, A. H. Características químicas e agronômicas associadas à degradabilidade da silagem de milho. 2000.93p. Dissertação (Mestrado em Fitotecnia)-Universidade Federal de Lavras, MG, Lavras.
HENRIQUE, W.; ANDRADE, J. B.; SAMPAIO. A. A. M. Silagem de milho, sorgo, girassol e suas consorciações. II. Composição bromatológica. In: REUNIÃO ANUAL DA SOCIEDADE BRASILEIRA DE ZOTECNIA, 35., 1998, Botucatu. Anais... Botucatu: SBZ, 1998. p.379-381.

HUNTER, R. B. Selection and evaluation procedures for wholeplant corn silage. Canadian Journal Plant Science, Ontário, v. 58, p.661-678, 1978.

KEPLIN, L. da A. S.; SANTOS, I. R dos. Silagem de milho. Campinas: Fundação ABC, 1996. 46p. (Manual)

MELO, W. M. C.; VON PINHO, R. G.; CARVALHO, M. L. M. Avaliação de cultivares de milho, para produção de silagem na região de Lavras, MG. Ciência e Agrotecnologia, Lavras, v.23, n.1, p.31-39, 1998.

MENEGAZ, L. A. Comparação qualitativa entre cultivares de milho (Zea mays L.) e sorgos (Sorghum bicolor L. Moench) forrageiro e duplo propósito na forma de silagem. In: REUNIÃO ANUAL DA SOCIEDADE BRASILEIRA DE ZOOTECNIA, 39., 2002, Recife, PE. Anais... Recife, PE: SBZ, 2002. 1 CD-Room.

NUSSIO, L. G. Cultura de milho para produção de silagem de alto valor alimentício. In: SIMPÓSIO SOBRE NUTRIÇÃO DE BOVINOS, 4., 1991, Piracicaba. Anais... Piracicaba: FEALQ, 1991. p.59-168.

PENATI, M. A. Relação de alguns parâmetros agronômicos e bromatológicos de híbridos de milho (Zea mays L.) com a produção, digestibilidade e o teor de matéria seca da planta. 1995. 97p. Dissertação (Mestrado em Ciência Animal e Pastagens)-Escola Superior de Agricultura Luiz de Queiroz, Piracicaba, 1995.

QUINBY, J. R. Sorghum improvement and genetics of growth. Texas: Texas A\& M Universit, College Station, 1974. 108p.

RAMALHO, A. R. Comportamento de famílias de meiosimãos em diferentes épocas de semeadura visando a produção de forragem de milho. 1999. 86p. Dissertação (Mestrado em Genética e Melhoramento de Plantas) Universidade Federal de Lavras, Lavras, 1999.

RESENDE, J. A. Características agronômicas, químicas e degradabilidade ruminal da silagem de sorgo. 2001. 53p. Dissertação (Mestrado em Zootecnia)-Universidade Federal de Lavras, Lavras, 2001.

RIBEIRO, P. H. E. Adaptabilidade e estabilidade de cultivares de milho em diferentes épocas de semeadura, níveis de adubação e locais do Estado de Minas Gerais. 1998. 126p. Tese (Doutorado em Genética e Melhoramento de Plantas)Universidade Federal de Lavras, Lavras, 1998.

SOUZA, F. R. S. Estabilidade de cultivares de milho (Zea mays L.) em diferentes épocas e locais de plantio em Minas Gerais. 1989. 80p. Dissertação (Mestrado em Genética e Melhoramento de Plantas)-Escola Superior de Agricultura de Lavras, Lavras, 1989. 
VALENTE, J. O. Manejo cultural do sorgo para forragem: Introdução. Sete Lagoas: MG: EMBRAPA/CNPMS, 1992. p.58. (Circular Técnica, 17)

VANSOEST, P. J.; ROBERTSON, J. B.; LEWIS, B. A. Methods for dietary fiber, neutral detergent fiber and nonstarch polysaccharides in relation to animal nutrition Journal of Dairy Science, Champaign, v.74, n.10, p.3583-3597, 1991.

VILLELA, T. E. A. Época de semeadura e de corte de plantas de milho para silagem. 2001. 80p. Dissertação (Mestrado em Fitotecnia)-Universidade Federal de Lavras, Lavras, 2001.
ZAGO, C. P. Cultura do sorgo para produção de silagem de alto valor nutritivo. In: SIMPÓSIO SOBRE NUTRIÇÃO DE BOVINOS, 4., 1991, Piracicaba. Anais... Piracicaba: FEALQ, 1991. p. 169-218.

WOLF, D. P. et al. Forage quality of mayze genotypes selected for extreme fiber concentrations. Crop Science, Madison, v. 33, n. 6, p. 1353-1359, Nov/Dec. 1993. 